\title{
Evaluation of the Effect of Low Level Laser Therapy and Synovial Fluid-Mesenchymal Stem Cells in Cases of Temporomandibular Joint Disorders \\ Original
} Article
Mosaad Abdaljawwad Khalifah

Department of Oral and Maxillofacial Surgery, Faculty of Dentistry, Kafrelsheikh

\begin{abstract}
Purpose: Temporomandibular joint disorders (TMD) might be the main cause of the non-dental orofacial pain. Various treatment modalities were introduced to treat that condition. Low level laser therapy (LLLT) had an anti-inflammatory and analgesic effect by enhancing the circulation and the cellular respiration. Synovial fluid-mesenchymal stem cells (SF-MSCs) had a regenerative and immunoregulatory effect. Both methods were applied as a treatment for the condition; but with no comparative studies in the literature. So, the current study aimed at evaluating their therapeutic effects.

Material and methods: A total of 27 patients with TMD in 40 TMJs were randomly divided into two equal groups. In group I, LLLT was applied at four successive weeks. For group II, SF-MSCs were isolated, proliferated and pooled at Passage 4 to be injected into the joint space at four successive weeks.

Results: SF-MSCs therapy was superior to the LLLT with regards to the enhancement of the maximum mouth opening and the reduction of the inflammatory cytokines IL-1 $\beta$ and TNF $\alpha$. With regards to interleukin-6, there was no statistically significant difference. However, for pain reduction, LLLT was better than SF-MSCs; but not after the third week.

Conclusion: Both treatment methods are accepted modalities; but SF-MSCs were more superior and had more sustained results.

Key Words: Cytokines, Low level laser therapy, Regeneration, Synovial fluid-mesenchymal stem cells, Temporomandibular joint disorders.

Received: 29 November 2020, Accepted: 27 January 2021.

Corresponding Author: Mosaad Abdaljawwad Khalifah, Department of Oral and Maxillofacial Surgery, Faculty of Dentistry, Kafrelsheikh University (Boys), Kafrelsheikh, Egypt, Tel.: +20452738074 , Mobile: +201008603084 , E-mail: mosaad_khalifa@den.kfs.edu.eg.
\end{abstract}

ISSN: 2090-097X, July 2020, Vol. 11, No. 3

\section{INTRODUCTION}

Temporomandibular joint disorders (TMD) are the main cause of pain in the orofacial region from a non-dental origin. TMD is a collective term describes clinical signs and symptoms involve temporomandibular joint (TMJ), muscles of mastication and other associated structures. Various invasive and non-invasive treatment modalities were applied and include NSAIDS, physiotherapy, occlusal therapy, splints and surgeries ${ }^{[1]}$.

The low level laser therapy (LLLT) as a treatment moderately is relatively a recent treatment method uses diode soft laser to generate a low-level energy with a wavelength range of $630-1300 \mathrm{~nm}$. At that energy level, it does not affect skin temperature, however, it has an anti-inflammatory and analgesic effect by enhancing the mitochondrial cellular respiration and increases ATP production. Moreover, it improves the blood microcirculation and lymphatic flow which reduce edema and decrease prostaglandin E2 and cyclooxygenase-2 levels. Although multiple reports recommended LLLT ${ }^{[2-5]}$, other authors did not recommend $\mathrm{it}^{\left[{ }^{6]}\right.}$.
Regeneration of the TMJ using stem cells is also another relatively recent maneuver to treat TMD. Mesenchymal stem cells (MSCs) could be isolated from many sources such like the bone marrow (BM), adipose tissue, umbilical cord, dental pulp, synovial fluid, can differentiate into different cell types. Their regenerative capacity and immunoregulatory properties enable their use in multiple conditions ${ }^{[8-10]}$ including TMD $^{[11-13]}$. High chondrogenic capability was reported on using stem cells from the tissues of the synovial joint ${ }^{[14,15]}$. Synovial fluid (SF) is a clear viscous liquid that is rich with hyaluronic acid. In normal joints, the number of synovial fluid-derived MSCs (SF-MSCs) is very low, however, it is reported that SF-MSCs markedly increased when the joint was injured and in osteoarthritic diseases ${ }^{[16,17]}$. Up to the best of my knowledge, there are no studies to compare the effect of the LLLT and the SF-MSCs therapy in cases of TMD. Therefore, the current study aimed at comparing the efficacy of LLLT and the SF-MSCs therapy in cased of TMD. 


\section{MATERIALS AND METHODS}

\section{Subjects:}

A total of 27 patients with TMD in 40 TMJs were included in the current study from the outpatient department of Oral and Maxillofacial Surgery department within the age range of 14 to 49 years (mean age 20.85 years) were included in the current study. The patients consisted of 17 females and 10 males. Inclusion criteria involved an otherwise healthy patient suffered clicking, peri-joint pain, and or limitation of mandibular movement who did not receive any medications within the previous three months. Exclusion criteria included any disease could affect the healing, hormonal disturbances (including diabetes mellitus), any bone or connective tissue disease, and bleeding or coagulation disorders. Patients were randomly divided into two equal groups using a computer permuted block stratified randomization generator (randomization. com).

\section{Study design:}

In group I patients, Low level Laser was generated by a $820 \mathrm{~nm}$ IR continuous GaAISs diode Laser (Mustang $2000+$, Russia) which has power density of $90 \mathrm{~mW} / \mathrm{cm}^{2}$ and energy density of $10 \mathrm{~J}^{[19-21]}$. As shown in (Figure 1), the laser was applied to the TMJ by a red probe for 30 seconds at three points which were: (1) just anterior to the external auditory meatus while the patient was maximally opening his mouth, (2) just anterior to the condyle while the patient was closing his mouth and (3) inside the external auditory canal with the probe directed anteromedially and while the patient was closing his mouth. The session was repeated every week for four weeks. Before the first session, points were marked on the tragus-outer canthus line at $10 \mathrm{~mm}$ anterior to the tragus and $2 \mathrm{~mm}$ inferior to the line. And the auriculotemporal nerve was anesthetized with Articaine $\mathrm{HCl} 4 \%$ with epinephrine 1:100,000 (Artpharmadent, Artpharma Co., Cairo, Egypt). Then, a synovial fluid (SF) sample was aspirated from the joint through the marked point for biochemical analysis. Another SF sample was aspirated once again from the joint through the marked point one week after the last session.



Figure 1: A case in group I where the low level laser therapy probe is applied anterior to the external auditory meatus.
For group II patients, SF-MSCs were collected and prepared as previously described as follows ${ }^{[21]}$. SF was aspirated from The TMJ and then was diluted at a ratio of $1: 6$ in a proliferation medium and was plated in $55-\mathrm{cm}^{2}$ Petri dishes. After 3 or 4 days, the medium was changed to remove the non-adherent cells. Cells expansion was performed by culturing in a proliferation medium containing Dulbecco's modified Eagle's medium with low glucose D6046 (DMEM-LG, Merck, Germany) (already contained $1 \%$ glutamine) supplemented with $10 \%$ fetal bovine serum F4135 (FBS, Sigma-Aldrich, Merck, Germany), $1 \mathrm{ng} / \mathrm{ml}$ basic fibroblast growth factor bFGF F5392 (Sigma-Aldrich, Merck, Germany) and $1 \%$ penicillin-streptomycin (Gibco, ThermoFisher, USA). The dishes were cultured at $37^{\circ} \mathrm{C}$ with $5 \%$ of humidified $\mathrm{CO}_{2}$. The medium was unchanged for the initial 3 days and then were changed twice per week along with the removal of the non-adherent cells until confluence. When the adherent cells reached about $80 \%$ of confluence, SF-MSCs were trypsinized (TrypsinEDTA $0.05 \%$, Gibco, ThermoFisher, USA) and plated at a density of $0.5 \times 106$ cells/dish. The medium was changed the following day and then every $2-3$ days. At the last stage passage (P3), pre-differentiation was performed by culturing SF-MSCs with differentiation medium composed of a Dulbecco's modified Eagle's medium with high glucose (DMEM-HG 6429) (SigmaAldrich, Merck, Germany) (already contained sodium pyruvate $(110 \mu \mathrm{g} / \mathrm{ml}))$ and supplemented with, bFGF $(1 \mathrm{ng} / \mathrm{ml}), \quad 1 \%$ penicillin-streptomycin (Gibco, ThermoFisher, USA), and chondrogenic supplements: proline $40 \mu \mathrm{g} / \mathrm{ml}$ (Sigma-Aldrich, Merck, Germany), L-ascorbic acid-2-phosphate $50 \mu \mathrm{g} / \mathrm{ml}$, and dexamethasone 107-M (Sigma-Aldrich, Merck, Germany). Then at passage 4 (P4), cells seeding in collagen sponges was performed using type III and I collagen sponges (95\% of type I collagen; diameter $5 \mathrm{~mm}$, thickness $2 \mathrm{~mm}$ ) (Symatèse Biomatériaux, Chaponost, France) at the density of 0.5 million cells per sponges and plated in a 48 -well plate at $37^{\circ} \mathrm{C}$ in humidified atmosphere containing $5 \% \mathrm{CO} 2(\mathrm{v} / \mathrm{v})$. Cells were pooled at $\mathrm{P} 4$ to be prepared for intra-articular injection at a concentration of 2.5 million cells per $50 \mu \mathrm{L}$ saline. Injection procedures were performed as follows. The surface of the skin of the pre-auricular region was disinfected with povidone iodine $10 \%$ antiseptic solution (Nile co, Egypt). Points were marked on the tragus-outer canthus line at $10 \mathrm{~mm}$ anterior to the tragus and $2 \mathrm{~mm}$ inferior to the line (Figure 2). The auriculotemporal nerve was anesthetized with Articaine $\mathrm{HCl} 4 \%$ with epinephrine 1:100,000 (Artpharmadent, Artpharma Co., Cairo, Egypt). A SF sample was aspirated from the joint through the marked point for biochemical analysis, followed by intra-articular injection of $1 \mathrm{~mL}$ of the prepared solution containing SF-MSCs at a concentration of 2.5 million cells per $50 \mu \mathrm{L}$ was performed at the marked point once every week for four weeks. Another SF sample was aspirated from the joint through the marked point one week following the last injection. 


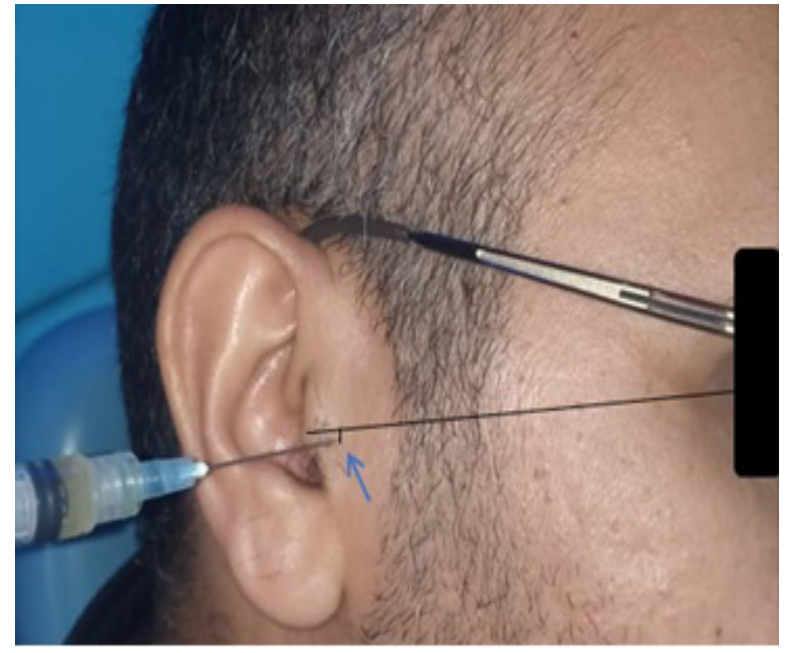

Figure 2: A case in group II where the synovial fluid-mesenchymal stem cells are injected into the joint through a point on the tragus-outer canthus line $10 \mathrm{~mm}$ anterior to the tragus and $2 \mathrm{~mm}$ inferior to the line as the blue line indicates.

All laboratory work was done at Alberg advanced labs.

This study complied with the Declaration of Helsinki (revised in 1975), and with CONSORT (Consolidated Standards of Reporting Trials) principles and the regional ethical review board approved the study. All patients provided informed consent.

\section{Investigated parameters:}

Two levels of assessment were conducted; the clinical level and the laboratory level investigation.

\section{Clinical assessment:}

Before the beginning of every session and at one week after the last session, the patient was asked to encircle the number that best described his pain level (if any) in the articular and or periarticular area (during rest or on function) on a numeric scale (NS) form (with a $10 \mathrm{~cm}$ line with equally spaced numbered markings from 0 to 10 , where 0 represented no pain and 10 represented the worst possible pain ${ }^{[22]}$. Also, the maximum mouth opening (MMO) was measured with a ruler in millimeters.

\section{Laboratory assessment:}

A total of $50 \mu \mathrm{L}$ of each eluted SF sample of SF were investigated to determine the concentration of the inflammatory cytokines interleukin-1 $\beta$ (IL-1 $\beta$ ), interleukin-6 (IL-6), and tumor necrosis factor- $\alpha$ (TNF $\alpha$ ) by an ELISA (Biotek IBL Hamburg, Germany). The results were read using a microplate reader at a wavelength of a $450-\mathrm{nm}^{[23]}$.

\section{Statistical analysis:}

Statistics were performed with SPSS software (version 19, IBM Co, USA).

\section{RESULTS}

\section{Clinical results:}

As table 1 depicts, pain level decreased within both groups over time but not after the fourth week. Pain level in group I was lower than that in group II only at the second and the third weeks; and otherwise there is no difference in-between. The preoperative difference was statistically insignificant.

Table 1: Pain score (using the numeric scale) for the both groups:

\begin{tabular}{|c|c|c|c|c|c|}
\hline & $\begin{array}{c}\text { Group I } \\
(\text { mean } \pm \text { SD*) }\end{array}$ & $\begin{array}{c}\text { Group II } \\
\left(\text { mean } \pm \mathrm{SD}^{*}\right)\end{array}$ & $\begin{array}{c}\text { Unpaired } \\
\text { student } t \text { test }\end{array}$ & $\begin{array}{c}\text { Intergroup } \\
\text { significance }\end{array}$ & Intragroup significance $¥$ \\
\hline preoperative & $7.5 \pm 0.3$ & $7.8 \pm 0.3$ & $\begin{array}{c}\mathrm{t}=2 \\
p=0.073\end{array}$ & insignificant & Not applicable \\
\hline At the $2^{\text {nd }}$ week & $4.9 \pm 0.5$ & $6.1 \pm 0.4$ & $\begin{aligned} \mathrm{t} & =8.831 \\
P & <0.0001\end{aligned}$ & significant & $\begin{array}{l}\text { Gp I: } \operatorname{sign}(\mathrm{t}=19.94, \\
P<0.0001) \\
\text { Gp II: } \operatorname{sign}(\mathrm{t}=15.21 \\
P<0.0001)\end{array}$ \\
\hline At the $3^{\text {rd }}$ week & $1.5 \pm 0.1$ & $4.6 \pm 0.2$ & $\begin{array}{c}\mathrm{t}=62 \\
P<0.0001\end{array}$ & significant & $\begin{array}{l}\text { Gp I: sign }(\mathrm{t}=29.82, \\
P<0.0001) \\
\text { Gp II: sign }(\mathrm{t}=15 \\
P<0.0001)\end{array}$ \\
\hline At the $4^{\text {th }}$ week & $1.2 \pm 0.5$ & $1.2 \pm 0.7$ & $\begin{array}{l}\mathrm{t}=0 \\
p=1\end{array}$ & insignificant & $\begin{array}{l}\text { Gp I: sign }(\mathrm{t}=2.63, \\
P=0.0122) \\
\text { Gp II: sign }(\mathrm{t}=20.89, \\
P<0.0001)\end{array}$ \\
\hline $\begin{array}{l}\text { At } 1 \text { week after } \\
\text { the last session }\end{array}$ & $1.1 \pm 0.3$ & $1.2 \pm 0.3$ & $\begin{array}{c}\mathrm{t}=1.054 \\
p=0.2985\end{array}$ & insignificant & $\begin{array}{l}\text { Gp I: insig }(\mathrm{t}=0.767, \\
P=0.448) \\
\text { Gp II: insignificant } \\
(\mathrm{t}=0, P=1)\end{array}$ \\
\hline
\end{tabular}


Table 2 depicts that despite the preoperative difference was statistically insignificant, MMO has enhanced over time in both groups on successive visits, however, that enhancement ceased in group I at the first week after the last session. Moreover, in every visit, the enhancement in group II was better than that in group I.

\section{Laboratory results:}

Table 3 depicts that all the inflammatory cytokines were reduced in both groups due to the treatment they received. Despite group II patients showed more reduction in both IL-1 $\beta$ and TNF $\alpha$, there was no significant difference between both groups regarding the reduction in IL-6. The preoperative difference was statistically insignificant.

Table 2: The maximum mouth opening (in $\mathrm{mm}$ ) for the both groups:

\begin{tabular}{|c|c|c|c|c|c|}
\hline & $\begin{array}{c}\text { Group I } \\
\left(\text { mean } \pm \mathrm{SD}^{*}\right)\end{array}$ & $\begin{array}{c}\text { Group II } \\
\left(\text { mean } \pm \mathrm{SD}^{*}\right)\end{array}$ & $\begin{array}{c}\text { Unpaired } \\
\text { student } t \text { test }\end{array}$ & $\begin{array}{c}\text { Intergroup } \\
\text { significance }\end{array}$ & Intragroup significance $¥$ \\
\hline preoperative & $12 \pm 0.9$ & $11 \pm 2.3$ & $\begin{array}{l}\mathrm{t}=1.812 \\
p=0.078\end{array}$ & insignificant & Not applicable \\
\hline At the $2^{\text {nd }}$ week & $25 \pm 1.1$ & $25 \pm 1.4$ & $\begin{array}{l}\mathrm{t}=0 \\
p=1\end{array}$ & insignificant & $\begin{array}{l}\text { Gp I: sign }(\mathrm{t}=40.91, \\
P<0.0001) \\
\text { Gp II: } \operatorname{sign}(\mathrm{t}=23.25, \\
P<0.0001)\end{array}$ \\
\hline At the $3^{\text {rd }}$ week & $33 \pm 2.0$ & $37 \pm 3.6$ & $\begin{array}{l}\mathrm{t}=4.344 \\
p<0.0001\end{array}$ & significant & $\begin{array}{l}\text { Gp I: sign }(\mathrm{t}=15.67, \\
P<0.0001) \\
\text { Gp II: sign }(\mathrm{t}=13.9, \\
P<0.0001)\end{array}$ \\
\hline At the $4^{\text {th }}$ week & $39 \pm 1.4$ & $41 \pm 0.5$ & $\begin{array}{l}\mathrm{t}=6.017 \\
p<0.0001\end{array}$ & significant & $\begin{array}{l}\text { Gp I: } \operatorname{sign}(\mathrm{t}=10.99, \\
P<0.0001) \\
\text { Gp II: sign }(\mathrm{t}=4.92, \\
P<0.0001)\end{array}$ \\
\hline $\begin{array}{l}\text { At } 1 \text { week after } \\
\text { the last session }\end{array}$ & $39 \pm 0.2$ & $42 \pm 1.1$ & $\begin{array}{c}\mathrm{t}=12 \\
p<0.0001\end{array}$ & significant & $\begin{array}{l}\text { Gp I: insignificant }(\mathrm{t}=0, P=1) \\
\text { Gp II: sign }(\mathrm{t}=3.7, P=0.0007)\end{array}$ \\
\hline
\end{tabular}

Table 3: Pre and post-operative values for the inflammatory cytokines in both groups:

\begin{tabular}{|c|c|c|c|c|c|c|}
\hline & \multicolumn{2}{|c|}{ IL-1 $\beta$} & \multicolumn{2}{|c|}{ IL-6 } & \multicolumn{2}{|c|}{$\mathrm{TNF} \alpha$} \\
\hline & $\begin{array}{c}\text { Preop } \\
\left(\text { mean } \pm \mathrm{SD}^{*}\right)\end{array}$ & $\begin{array}{c}\text { Postop } \\
\left(\text { mean } \pm \mathrm{SD}^{*}\right)\end{array}$ & $\begin{array}{c}\text { Preop } \\
(\text { mean } \pm \text { SD*) }\end{array}$ & $\begin{array}{c}\text { Postop } \\
\left(\text { mean } \pm \mathrm{SD}^{*}\right)\end{array}$ & $\begin{array}{c}\text { Preop } \\
\left(\text { mean } \pm \mathrm{SD}^{*}\right)\end{array}$ & $\begin{array}{c}\text { Postop } \\
\left(\text { mean } \pm \mathrm{SD}^{*}\right)\end{array}$ \\
\hline Group I & $15.6 \pm 0.2$ & $3 \pm 0.3$ & $12.2 \pm 2.4$ & 0 & $27 \pm 4.6$ & $7.7 \pm 0.2$ \\
\hline Group II & $15.5 \pm 1.3$ & $1.01 \pm 0.9$ & $11.3 \pm 1.9$ & 0 & $25 \pm 0.1$ & 0 \\
\hline $\begin{array}{l}\text { Student } t \text { vales } \\
\text { (intergroup) }\end{array}$ & $\begin{array}{c}\mathrm{t}=0.34 \\
P=0.7357 \\
\text { insignificant }\end{array}$ & $\begin{array}{c}\mathrm{t}=9.38 \\
p<0.0001 \\
\text { significant }\end{array}$ & $\begin{array}{c}\mathrm{t}=1.315 \\
P=0.196 \\
\text { insignificant }\end{array}$ & $\begin{array}{c}- \\
- \\
\text { insignificant }\end{array}$ & $\begin{array}{c}\mathrm{t}=1.944 \\
P=0.0593 \\
\text { insignificant }\end{array}$ & $\begin{array}{c}\mathrm{t}=172.2 \\
p<0.0001 \\
\text { significant }\end{array}$ \\
\hline $\begin{array}{l}\text { Student } t \text { vales } \\
\text { intragroup: Gp I }\end{array}$ & \multicolumn{2}{|c|}{$\begin{array}{c}\mathrm{t}=168.7 \\
p<0.0001 \\
\text { significant }\end{array}$} & \multicolumn{2}{|c|}{$\begin{array}{c}\mathrm{t}=22.73 \\
p<0.0001 \\
\text { significant }\end{array}$} & \multicolumn{2}{|c|}{$\begin{array}{l}\mathrm{t}=15.83 \\
p<0.0001 \\
\text { significant }\end{array}$} \\
\hline $\begin{array}{l}\text { Student t vales } \\
\text { intragroup: Gp } \\
\text { II }\end{array}$ & \multicolumn{2}{|c|}{$\begin{array}{l}\mathrm{t}=40.98 \\
p<0.0001 \\
\text { significant }\end{array}$} & \multicolumn{2}{|c|}{$\begin{array}{c}\mathrm{t}=26.6 \\
p<0.0001 \\
\text { significant }\end{array}$} & \multicolumn{2}{|c|}{$\begin{array}{c}\mathrm{t}=1118 \\
p<0.0001 \\
\text { significant }\end{array}$} \\
\hline
\end{tabular}

IL-1 $\beta$ : interleukin-1 $\beta$, IL-6: interleukin-6, TNF $\alpha$ : tumor necrosis factor- $\alpha$, Preop: preoperative, Postop: at 1 week after the last session, * SD: Standard deviation; $\$$ : the significance between the values of both groups at the same session at $\alpha=0.05$, $¥:$ the significance within each group tested to the values of the previous session at $\alpha=0.05$, Gp I: group I, Gp II: grop II, sign: significant, insig: insignificant. 


\section{DISCUSSION}

Temporomandibular joint disorders (TMD) are the main cause of the non-dental orofacial pain ${ }^{[1]}$. Various invasive and non-invasive treatment modalities were applied including the low level laser therapy (LLLT) which has an anti-inflammatory and analgesic effect by enhancing the mitochondrial cellular respiration and increases ATP production. It decreases inflammatory cytokines such as prostaglandin E2 and cyclooxygenase-2 levels. Moreover, it improves the blood microcirculation and lymphatic flow which reduce edema. Many and multiple differences in the laser type, wave length, period of application, area of application led to variant and sometimes contradicting results ranging from the grate support to considering it has the same effect of a placebo ${ }^{[2-}$ 6]. Mesenchymal stem cells (MSCs) from different sources were used in the treatment of TMDs for their regenerative capacity and immunoregulatory properties ${ }^{[8-13]}$. Synovial fluid-derived MSCs (SF-MSCs) are very little in normal joints, but increases in injured and osteoarthritic joints ${ }^{[16}$, 17]. SF-MSCs have high chondrogenic capability, that is why it is used to treat injured tissues in the joint ${ }^{[14,15]}$. Up to the best of my knowledge, there are no studies to compare the analgesic and anti-inflammatory effect of the LLLT to the regenerative effect of SF-MSCs in cases of TMD. Therefore, the current study aimed at comparing the anti-inflammatory analgesic strategy of LLLT versus the regenerative strategy of the SF-MSCs therapy to treat TMD.

In the current study, the inclusion and exclusion criteria were set to allocate a homogenous study population has no healing problems as far as possible. That was reflected in the insignificant difference between both groups regarding the preoperative values of the studied parameters. They were selected from patients who did not receive treatment in the previous period to assure no interaction of these treatment with the current investigated modalities. LLLT reduced pain faster than did SF-MSCs therapy; but as the fourth week began, LLLT had no superior effect over SFMSCs therapy. Moreover, at the fifth week, both treatments did not show more palliative effect than the previous week. That might mean that LLLT had a marked direct analgesic effect by enhancing the circulation; and so washing away the inflammatory cytokines and enhancing the intracellular and the extracellular respiration of the cells, and thus eliminated the noxious stimuli irritating the nerve endings and decreased the edema which might compressed over the nerve. The regenerative effect might requested more time to exhibit that analgesic effect by ceasing the degenerative process and the associated release of noxious substances and then reversing it by regenerating the torn tissues and the necrotic cells. Once the joints in both groups were stabilized, the effect of both treatment was comparable.

With regards to the enhancement of in the mouth opening, LLLT might reached that effect by merely removing the noxious stimuli and thus reducing the pain-associated trismus. However, regeneration stopped the degeneration process which might have resulted in mechanical roughness caused limitation of the movement. The immunoregulatory and analgesic effect of the SFMSCs also aides in freeing the movement. That might gave the reason why these two strategies went comparably within the first period of the treatment. And at the fourth week, the cumulative effect of the regeneration exceeded the effect of the LLLT which failed to show further movement freeing effect. Regeneration is a sustained cumulative process in comparison with the simpler anti-inflammatory process of the LLLT.

With regards to the inflammatory cytokines reduction, both groups were effective but regeneration was more effective for IL-1 $\beta$ and TNF $\alpha$; but not for IL-6. That might be the result of the mechanism by which LLLT decreased the cytokines which might was only removing the produced cytokines and not preventing its formation as was in the case of the regeneration. Another reason might be the sustained cumulative effect of regeneration which with time replaced the cytokines-releasing cells with new healthy cells and thus had a more pronounced effect.

The results of the current study emphasized the results of multiple studies advocated LLLT ${ }^{[2-5]}$ and its antiinflammatory analgesic effect provided by circulation enhancement, but was in disagree with other studies which considered LLLT ineffective ${ }^{[6]}$. That weakness point in the studies of the LLLT might issue from the inconsistency in the protocol of LLLT application as there were wide controversy about the best protocol regarding the mechanism of laser generation, wave length value, period of application, area of application, and other factors. That led to no generally accepted LLLT protocol ${ }^{[6,24-27]}$. With regards to the stem cells therapy, the current study agrees with the previous work of multiple authors ${ }^{[8-15]}$ who advocated regeneration as a mechanism of replacing the diseased cells with new healthy cells capable of producing a new SF which led to lubricating the joint and so reducing pain and enhancing the movement, in addition to reducing the noxious stimuli to the nerve and even regenerating the nerve endings themselves on the long run and reducing the concentration of the inflammatory cytokines in the SF.

\section{CONCLUSION}

Temporomandibular joint disorders might be the main cause of the non-dental orofacial pain. Various invasive and non-invasive treatment modalities were applied. LLLT had an anti-inflammatory and analgesic effect by enhancing the circulation and the cellular respiration. SFMSCs had a regenerative and immunoregulatory effect. In the current study, SF-MSCs therapy was superior to the LLLT with regards to the enhancement of the MMO, and the reduction of the inflammatory cytokines. However, for pain reduction, LLLT was better than SF-MSCs; but not after the third week and even at the fifth week. Both 
treatment methods are accepted modalities, but SF-MSCs were more superior and had more sustained action.

\section{CONFLICT OF INTEREST}

The authors declare no conflict of interest.

\section{REFERENCES}

1. Shinozaki, Ewerson Bertolini, Mateus Bertolini Fernandes dos Santos, Luiz Kioaki Okazaki, Leonardo Marchini, and Aldo Brugnera Junior. "Clinical Assessment of the Efficacy of LowLevel Laser Therapy on Muscle Pain in Women with Temporomandibular Dysfunction, by Surface Electromyography." Brazilian Journal of Oral Sciences 9, no. 4 (December 2010): 434-38. http:// revodonto.bvsalud.org/scielo.php? script $=\mathrm{sci}$ abstract\&pid=S167732252010000400004-\&lng= pt\&nrm=iso\&tlng=en.

2. Melis, Marcello, Massimiliano Di Giosia, and Khalid H. Zawawi. "Low Level Laser Therapy for the Treatment of Temporomandibular Disorders: A Systematic Review of the Literature." Cranio: The Journal of Craniomandibular Practice 30, no. 4 (October 2012): 304-12. https://doi.org/10.1179/ crn.2012.045.

3. Xu, Gang-Zhu, Jie Jia, Lin Jin, Jia-Heng Li, ZhanYue Wang, and Dong-Yuan Cao. "Low-Level Laser Therapy for Temporomandibular Disorders: A Systematic Review with Meta-Analysis." Pain Research \& Management 2018 (May 10, 2018). https://doi.org/10.11554230583/2018/.

4. Douglas de Oliveira, Dhelfeson, Frederico Lages, Raphael Guimarães, Túlio Pereira, Adriana Botelho, José Glória, Karine Tavano, Patricia Gonçalves, and Olga Flecha. "Do TMJ Symptoms Improve and Last across Time after Treatment with Red $(660 \mathrm{Nm})$ and Infrared $(790 \mathrm{Nm})$ Low Level Laser Treatment (LLLT)? A Survival Analysis." Cranio: The Journal of Craniomandibular Practice 35 (February 20, 2017): 1-7. https://doi.org/10.10 $8008869634.2017 .1292176 /$.

5. Pai, Annapoorna Y., Gillian Watson, Michael Nugent, and Justin Durham. "Low Level Laser Therapy (LLLT) in the Treatment of a Mixed Cohort of Patients with Temporomandibular Disorders (TMD): A Case Series." British Journal of Oral and Maxillofacial Surgery 55, no. 10 (December 1, 2017): e187. https://doi. org/10.1016/j.bjoms.2017.08.289.
6. Shobha, R., Veena S. Narayanan, BS Jagadish Pai, H. P. Jaishankar, and M. J. Jijin. "Low-Level Laser Therapy: A Novel Therapeutic Approach to Temporomandibular Disorder - A Randomized, Double-Blinded, Placebo-Controlled Trial." Indian Journal of Dental Research 28, no. 4 (July 1, 2017): 380. https://doi.org/10.4103/ijdr. IJDR_345_15.

7. Pittenger, M. F., A. M. Mackay, S. C. Beck, R. K. Jaiswal, R. Douglas, J. D. Mosca, M. A. Moorman, D. W. Simonetti, S. Craig, and D. R. Marshak. "Multilineage Potential of Adult Human Mesenchymal Stem Cells." Science (New York, N.Y.) 284, no. 5411 (April 2, 1999): 143-47. https://doi.org/10.1126/science.284.5411.143.

8. Jo, Chris Hyunchul, Young Gil Lee, Won Hyoung Shin, Hyang Kim, Jee Won Chai, Eui Cheol Jeong, Ji Eun Kim, et al. "Intra-Articular Injection of Mesenchymal Stem Cells for the Treatment of Osteoarthritis of the Knee: A Proof-of-Concept Clinical Trial." Stem Cells (Dayton, Ohio) 32, no. 5 (May 2014): 1254-66. https://doi.org/10.1002/ stem.1634.

9. Bartolucci, Jorge, Fernando J. Verdugo, Paz L. González, Ricardo E. Larrea, Ema Abarzua, Carlos Goset, Pamela Rojo, et al. "Safety and Efficacy of the Intravenous Infusion of Umbilical Cord Mesenchymal Stem Cells in Patients With Heart Failure." Circulation Research 121, no. 10 (October 27, 2017): 1192-1204. https://doi. org/10.1161/CIRCRESAHA.117.310712.

10. Huang, Yi-Zhou, Hui-Qi Xie, Antonietta Silini, Ornella Parolini, Yi Zhang, Li Deng, and YongCan Huang. "Mesenchymal Stem/Progenitor Cells Derived from Articular Cartilage, Synovial Membrane and Synovial Fluid for Cartilage Regeneration: Current Status and Future Perspectives." Stem Cell Reviews and Reports 13, no. 5 (October 1, 2017): 575-86. https://doi. org/10.1007/s120151-9753-017-.

11. Zhang, Shipin, Adrian U. J. Yap, and Wei Seong Toh. "Stem Cells for Temporomandibular Joint Repair and Regeneration." Stem Cell Reviews and Reports 11, no. 5 (October 2015): 728-42. https:// doi.org/10.1007/s120159604--015-X.

12. Chen, K., C. Man, B. Zhang, J. Hu, and S. -S. Zhu. "Effect of in Vitro Chondrogenic Differentiation of Autologous Mesenchymal Stem Cells on Cartilage and Subchondral Cancellous Bone Repair in 
Osteoarthritis of Temporomandibular Joint." International Journal of Oral and Maxillofacial Surgery 42, no. 2 (February 1, 2013): 240-48. https://doi.org/10.1016/j.ijom.2012.05.030.

13. Lu, L., X. Zhang, M. Zhang, H. Zhang, L. Liao, T. Yang, J. Zhang, L. Xian, D. Chen, and M. Wang. "RANTES and SDF-1 Are Keys in Cell-Based Therapy of TMJ Osteoarthritis." Journal of Dental Research 94, no. 11 (November 2015): 1601-9. https://doi.org/10.11770022034515604621/.

14. Islam, A, Ak Hansen, C Mennan, and I MartinezZubiaurre. "Mesenchymal Stromal Cells from Human Umbilical Cords Display Poor Chondrogenic Potential in Scaffold-Free Three Dimensional Cultures." European Cells and Materials 31 (May 27, 2016): 407-24. https://doi. org/10.22203/eCM.v031a26.

15. Su, Xinlin, Wei Zuo, Zhihong Wu, Jun Chen, Nan Wu, Pei Ma, Zenan Xia, et al. "CD146 as a New Marker for an Increased Chondroprogenitor Cell Sub-Population in the Later Stages of Osteoarthritis.” Journal of Orthopaedic Research: Official Publication of the Orthopaedic Research Society 33, no. 1 (January 2015): 84-91. https:// doi.org/10.1002/jor.22731.

16. Matsukura, Yu, Takeshi Muneta, Kunikazu Tsuji, Hideyuki Koga, and Ichiro Sekiya. "Mesenchymal Stem Cells in Synovial Fluid Increase After Meniscus Injury." Clinical Orthopaedics and Related Research 472, no. 5 (May 2014): 135764. https://doi.org/10.1007/s119994-3418-013-.

17. Anraku, Yoshihisa, Hiroshi Mizuta, Akira Sei, Satoshi Kudo, E. Nakamura, Kei Senba, and Yuji Hiraki. "Analyses of Early Events during Chondrogenic Repair in Rat Full-Thickness Articular Cartilage Defects." Journal of Bone and Mineral Metabolism 27 (March 1, 2009): 272-86. https://doi.org/10.1007/s007740038--009-x.

18. Carroll, James D., Michael R. Milward, Paul R. Cooper, Mohammed Hadis, and William M. Palin. "Developments in Low Level Light Therapy (LLLT) for Dentistry." Dental Materials: Official Publication of the Academy of Dental Materials 30, no. 5 (May 2014): 465-75. https://doi. org/10.1016/j.dental.2014.02.006.

19. Bjordal, Jan M, Christian Couppé, Roberta T Chow, Jan Tunér, and Elisabeth Anne Ljunggren. "A Systematic Review of Low Level Laser Therapy with Location-Specific Doses for Pain from Chronic Joint Disorders." Australian
Journal of Physiotherapy 49, no. 2 (January 1, 2003): 107-16. https://doi.org/10.1016/S00046-60127(14)9514.

20. Orhan, Kaan, Umut Aksoy, Deniz C. CanKarabulut, and Atakan Kalender. "Low-Level Laser Therapy of Dentin Hypersensitivity: A Short-Term Clinical Trial." Lasers in Medical Science 26, no. 5 (September 2011): 591-98. https://doi.org/10.1007/s101039-0794-010-.

21. Neybecker, Paul, Christel Henrionnet, Elise Pape, Didier Mainard, Laurent Galois, Damien Loeuille, Pierre Gillet, and Astrid Pinzano. "In Vitro and in Vivo Potentialities for Cartilage Repair from Human Advanced Knee Osteoarthritis Synovial Fluid-Derived Mesenchymal Stem Cells." Stem Cell Research \& Therapy 9, no. 1 (November 28, 2018): 329. https://doi.org/10.1186/s13287-0182-1071.

22. Farrar, J. T., J. P. Young, L. LaMoreaux, J. L. Werth, and R. M. Poole. "Clinical Importance of Changes in Chronic Pain Intensity Measured on an 11-Point Numerical Pain Rating Scale." Pain 94, no. 2 (November 2001): 149-58. https://doi. org/10.1016/s03049-00349(01)3959-.

23. Gulen, Huseyin, Hanife Ataoglu, Seyfullah Haliloglu, and Kubilay Isik. "Proinflammatory Cytokines in Temporomandibular Joint Synovial Fluid before and after Arthrocentesis." Oral Surgery, Oral Medicine, Oral Pathology, Oral Radiology, and Endodontics 107, no. 5 (May 2009): e14-. https://doi.org/10.1016/j. tripleo.2009.02.006.

24. Ayyildiz, Simel, Faruk Emir, and Cem Sahin. "Evaluation of Low-Level Laser Therapy in TMD Patients." Case Report. Case Reports in Dentistry. Hindawi, October 26, 2015. https://doi. org/10.1155424213/2015/.

25. Mazzetto, Marcelo Oliveira, Takami Hirono Hotta, and Renata Campi de Andrade Pizzo. "Measurements of Jaw Movements and TMJ Pain Intensity in Patients Treated with GaAlAs Laser." Brazilian Dental Journal 21, no. 4 (2010): 356-60. https://doi.org/10.1590/S010364402010000400012 .

26. Hotta, Patrícia Tiemy, Takami Hirono Hotta, César Bataglion, Solange Aparecida Bataglion, Elaine Angélica de Souza Coronatto, Selma Siéssere, and Simone Cecilio Hallak Regalo. "Emg Analysis after Laser Acupuncture in Patients with Temporomandibular Dysfunction (TMD). 
Implications for Practice." Complementary Therapies in Clinical Practice 16, no. 3 (August 1, 2010): 158 - 60. https://doi.org/10.1016/j. ctcp.2010.01.002.

27. Maia, Mila Leite de Moraes, Leonardo Rigoldi Bonjardim, Jullyana de Souza Siqueira
Maria Amália Gonzaga Ribeiro, Buintanserilherme Martins Maia, and Paulo César Rodrigues Conti. "Effect of Low-Level Laser Therapy on Pain Levels in Patients with Temporomandibular Disorders: A Systematic Review." Journal of Applied Oral Science 20, no. 6 (December 2012): 594 - 602. https://doi. org/10.1590/S167877572012000600002-. 